DOI https://doi.org/10.32782/2305-9389/2020.23.04

УДК 929.52-027.553(477.82)

Філюк Оксана,

викладач ииклової комісії суспільних та художньо-мистецьких дисииплін Комунального закладу вищої освіти «Луиький педагогічний коледж»

Волинської обласної ради

Срко Галина, викладач-методист,

голова циклової комісії суспільних та художньо-мистецьких дисциплін Комунального закладу вищої освіти «Луцький педагогічний коледж»

Волинської обласної ради

Галан Ольга, викладач ииклової комісії суспільних та художньо-мистецьких дисциплін Комунального закладу вищої освіти «Луцький педагогічний коледж» Волинської обласної ради

\title{
ІСТОРІЯ РОДИНИ ВОЛИНСЬКИХ СЛОВАКІВ ЗАЛЕТ: СПОГАДИ ЖИТЕЛЬКИ СЕЛА БОРАТИН ГАННИ МАТВЇ̈ВНИ ЗАЙ
}

У статті розповідається про родину волинських словаків Залет із Прямівщини. На основі спогадів Ганни Матвївни Зай, доньки голови родини Матвія Матвійовича Залети, описано історію їх переселення як оптантів у 1947 році, зокрема мотиви переїзду, труднощі, з якими стикалася родина після переїзду, заняття і життєві шляхи членів родини. Спогади створюють яскравий детальний опис повоєнної Волині, дають змогу відтворити окремі сторінки минулого. Як виявилось, доля приготувала чимало випробувань на новій землі для родини Залет.

Якщо добровільний вияв волинських чехів на виїзд з Украӥни у 1947 рочі не викликає сумнівів, то щзодо населення Словаччини є певні суперечливі моменти.

I спогади очевидиів тих подій дають змогу хоча б частково їх вирішити. Водночас спогади спонукають до більш детального вивчення цьвого питання і подальшого розширення джерельної бази.

Наприкінці січня 1947 р. зі Східної Словаччини вирушили ешелони з оптантами на Волинь. Тисячі людей повірили агітаторам, які їздил по східнословацьких селах і розповідали про «щасливе» життя в Радянському Союзі. Представники радянського уряду обіияли надати все необхідне для проживання на новому місиі поселення в селах, де раніше мешкали «волинські чехи». Спочатку частково так і було: надали житло, землю, інвентар, тобто те, шьо залишилося після виїзду звідси чехів-колоністів до Чехословаччини. Тільки дійсність виявилася зовсім іншою: пізніше майже все, навіть те, щуо було привезено селянами зі Словаччини, радянська влада і відібрала, створивши в місиях проживання оптантів колгоспи.

Замість добротноїхати в Словаччині радянська влада дала родині Залет будинок із протікаючим дахом, азамість господарства з коровами і кіньми - бідність та голод. Сподівання були великими, але не меншим було і розчарування. Такою виявилася иіна довіри простого словаџького селянина з села Лютина до радянської влади. I спогади очевидиџі, яка разом із батьками, братами і сестрами (в родині було 8 дітей), пережсла ті складні часи, відчула на собі всі ті поневіряння, є правдивою історією життя однієї з родин волинських оптантів зі Словаччини.

Ключові слова: оптація, Словаччина, Волинь, Боратин, спогади.

Filiuk Oksana, Yerko Halyna, Halan Olha. History of the family of Volyn Slovaks Zalets: memories of a citizen from the village Boratyn Zai Hanna Matvijivna

In this article tells a story about the family of volyn Slovaks Zalets from Presov Region. The story is written on a basis of memories of Zai Hanna Matvijivna, a daughter of Zaleta Matvij Matvijovych. It describes how they immigrate as optants in 1947, in particular what were the motives of their relocation, which difficulties they have faced after the move, activities and life paths of the family members. These memories create a bright and detailed description of post-war Volhynia and enable to recreate some pages from the past. It turned out that the fate prepared a lot of challenges on the new land for Zalet family.

While there is no uncertainty about Volyn Czecks voluntary leaving Ukraine in 1947 there are some controversial moments about the Slovak citizens. And memories of the witnesses of those happenings give us a possibility to make it at least a little bit clearer. At the same time memories urge to research this question more precise and to extend the accumulation of sources.

At the end of January 1947 trains with optants departed from South Slovakia to Volyn region. Thousands of people believed the agitators who have been visiting Slovak villages and telling people about "happy life" in Soviet Union. 
Representants of the Soviet government promised to give everything that was necessary to live in a new place as well as housing in the villages where the Volyn Czechs had lived earlier. It was like this at the beginning: a house, a land and household objects - everything that was left there form Czech colonists which moved to Czechoslovakia. However, the reality turned out to be different later: the Soviet government expropriated almost everything, even the stuff that was brought from Slovakia and established kolkhozes in the areas where the optants lived. Instead of a well-furnished place of residence in Slovakia family Zalet got a house with leaking roof and instead of cows and horses - poverty and hunger. Hopes were huge, but the disappointment was not smaller. This was the price a farmer from the village Liytyn paid for the trust in the Soviet government. And the memories of a witness who has lived through those difficult times together with her parents and siblings (there were 8 children in the family) and felt all those roams tell us the true story of life of Volyn optants from Slovakia.

Key words: potation, Slovakia, Volyn, Boratyn, memories.

10 липня 1946 р. між Радянським Союзом та Чехословацькою республікою була укладена «Угода між Урядом СРСР і Урядом ЧСР про право оптації та переселення відповідно громадян чеської і словацької національності, які мешкають у СРСР на території колишньої Волинської губернії, і чехословацьких громадян української, російської і білоруської національності, які мешкають на території Чехословаччини». На іiї базі розгорнулася «волинська акція» уряду ЧСР (1946-1947 рр.) із повернення понад 33 тис. волинських чехів до країни і зустрічний потік чехословацьких переселенців, згідно з даними радянської сторони, - понад 8,5 тис. осіб, в основному українців із Східної Словаччини, - на Волинь (в Україну).

Найвідоміший дослідник історії українців у Словаччині І. Ванат подає чергову детальну статистику родин і чисельності оптантів-переселенців по округах Східної Словаччини (Пряшівщини): Бардіївський - 1281 сім'я (5904 особи), Гуменський - 238 (1051 особа), Міжлабірський - 706 (3088 осіб), Пряшівський - 440 (1972 особи). Загалом по Пряшівщині - 2665 родин, або 1205 осіб [1].

У 1947 рр. між Радянським Союзом і Чехословацькою Республікою відбувся взаємообмін населенням на принципі оптації між Пряшівщиною і Волинню.

Маловживаний в українській історіографії міжнародно-правничий термін «оптація» означає добровільний вибір громадянства (від лат. optatio - вибір).

Із 1872 по 1947 pp. у межах нинішнього Боратина існував населений пункт, якого немає нині на карті, але про який ще можуть розповісти сивочолі старожили. Збереглася низка садиб, в яких нині проживають і господарюють теперішні боратинці. Йдеться про колонію переселенців чехів, названу Чеським Боратином [2].

У паспорті жительки села Боратин Луцького району Ганни Матвіївни Зай у графі «Національність» вказано «українка», а у графі «Місце народження» - с. Лютина, Словаччина.

Нижче наведені спогади жительки села Боратин Луцького району Ганни Матвіївни Зай (дівоче прізвище Залета).

«У вересні 1946 р. мені виповнилося сім років, а в лютому 1947 р. ми приїхали в Україну.

Народилася я 19 вересня 1939 р. в селі Лютина, Собіновський район, Прешовська область. Тато був Залета Матвій Матвійович 1904 р. н. Мама - Залета Анна Андріївна ( дівоче прізвище - Радачовська), теж словачка.

Я пам'ятаю, як в 1946 р. робили збори в школі і я з татом туди ходила, мені цікаво було. Приїжджала якась росіянка і агітувала на переїзд до України, говорила, яка тут земля добра, чорнозем родючий, рівнина. А я Вам скажу: люди того загітувалися, що в нас в Лютині дуже гірська місцевість, дуже погано обробляти землі. Я пам'ятаю, як запрягали корови в ярма і, щоб підвода не покотилася з гори, колеса обв'язували ланцюгами і так гальмували. I через те чоловіки по 40, 42 роки (всі ж вони хазяї були), думали: діти ж підростають, а землі дадуть «скільки хочеш, стільки і бери», і земля начебто безплатна...

На той час у нас у сім’ї було 7 дітей: Михайло 1929 р. н., Марія 1931 р. н., Ольга 1933 р. н., Гелена 1937 р. н., Анна 1939 р. н., Тереза 1942 р. н., Ірина 1945 р. н. А вже тут, в Україні в мами народився найменший син Андрій 19 червня 1948 р.

Старшому брату Михайлу було на той час 17 років, і він працював в Чехії на фабриці і допомагав нам грошима, мама хотіла, щоб хоча б він залишився, але тато захотів, щоб всі діти були разом.

Тато дуже хотів їхати, бо їхали його рідний брат і сестра. А 3 маминої родини не їхав ніхто, і вона плакала день і ніч - не хотіла їхати. Мама навіть ходила в ту школу, де записували, щоб забрати документи, але їй сказали, що тільки тато може це зробити.

Жили ми досить непогано на ті часи: ліси кругом, ми 3 корову тримали, будиночок мали, тільки ділили його з татовим братом. Будинок стоїть до цього часу. Я, коли їздила туди, бачила його. Тато на той час навозив із лісу каменю, вже мав будуватись, але тут пішла така агітація, один на одного 
дивились... 3 нашого села поїхали десь 28 сімей, а може й 30, і оселилися тут, у Боратині. Пізніше частина сімей розселилися по інших місцях, у тому числі і в Ровенську область. То приїхали:

Залета - 3, Бородач - 2 сім'ї, Варголяк - 2, Пігула - 3, Семан - 1, Осиф - 1 , Міко - 1, Черняк - 2, Ілько - 1, Михайлик - 1, Фалат - 2, Дугань - 2, Чапістрак -2 , Фекета -3 , Герег - 1, Дугальчик -1 , Коцвар (прізвисько) - 1 .

Тут, у Боратині, жили чехи, мабуть, років зо сімдесят. Вони тут хазяйнували, але коли почули, що тут будуть організовувати колгосп, ну і після війни тут становище було всяке, свої вбивали своїх, вони полякалися і стали требувати своє правітєльство, щоб їх забрали додому. Їм дозволили. I на їхнє місце стали агітувати нас. У переселенському листі пише: на територію Союза переселяються граждане із Чехословацької Республіки по національності українці, білоруси і росіяни. А за словаків там не пише. Як так вийшло, той не знаю, що нас агітували. Я вам скажу: на місці й камінь обростає. Чого було звідти їхати? Нам там всього вистачало. Нас тут українці-то не обіжали, гарно відносились. Проблеми були тільки з однією сім'ю: поки ми їхали, переселенці з Польщі, які раніше нас переселялися, десь чи то з Одеської області чи звідки, як тільки почули, що ми їдемо, то самовільно зайняли половину нашої хати. То майже в кожній хаті були половина словаків, а половина - переселенці з-за Буга.

Тоді голод був. Люди з собою везли зерно, картоплю... то картопля в той мороз померзла, товарний вагон, снігу було багато. Три корови везли, чотири овечки, двоє свиней, зерно і курей, сіно і солома. Чоловіки весь час були біля худоби, шо вони намучились там бідні: і напоїти, і накормити, і ще й дивитись, щоб не вкрали.

Дорога-то була недовгою. Діти-то раділи, ми ніколи на машині то і не їхали, а тут поїздом...

Як приїхали сюди, то багато хто захотів відразу повернутись. Але ніхто нікому не дозволив. Навіть у відпустку до 1960 року не можна було їхати, не випускали. Одна жінка втікала, то сказали, що посадять у тюрму. А розказували, що ще одна то змогла втекти: залізла в товарний вагон, лягла в жолоб, накрилася соломою і так проїхала.

Поселили нас в хату чеха Швейдера, кажуть, він був головою сільради. Нас ще в хаті дочекалася чешка і залишила нам в погребі картоплі на перший час. Тільки ту картоплю однієї ночі в нас вкрали.

Але хата була погана: дуже текла криша, половина хати була накрита новою цинковою бляхою, а половина - толлю. Як пішли дощі, то підставляли і балії, і відра. Мама все плакала, не могла на те дивитись. Картопля вся померзла, дітей годувати треба. Так вона і померла в 1955 році, коли мала 49 років тільки. Добре хоч зерно було, ми мали такий ручний млиночок, то все мололи. Ми все перемелювали, в тому числі і кукурудзу, і варили кулешу і пекли хлібчики в духовці. Піч була само собою, а духовка на 1 бляшку. 3 дровами тільки була проблема велика. Найменшій сестрі, Ipi, тоді було півроку.

Ми, двоє дітей, Гелена і Анна, пішли в перший клас. Школа була в чеському будинку, де колись був дєтдом. Вчителька викладала українською мовою, якої ми на той час не знали. У класі було зо 30 учнів. Ми ладнали зі всіма дітьми.

Коли прийшла весна і треба було садити картоплю, то самий старший брат Михайло зі старшою сестрою Марією ходили у Великий Боратин і жебрали картоплю, мусили йти... Давали хто скільки міг. Нарешті попали до однієї жінки, вона запитала, чиї ми діти і в хаті якого чеха живемо. Вони сказали, що в хаті Швейдера. Виявилось, що та жінка служила в Швейдера... То вона дала найбільш картоплі. Ту картоплю мама чистила із грубим лушпинням, так щоб тим лушпинням із вічками посадити город. $\mathrm{A}$ із середньої частини картоплі варила нам суп.

Тато продав корову і купив коня. Тут якраз колгоспи почали організовуватись. У нас тут клуня чеська велика була, така стодола для сіна і соломи. Посередині в клуні був коридор, там тато зі старшим братом ціпами молотили зерно.

Пам'ятаю, як держпоставки заставляли відразу здавати. Шо вони робили... Люди ше тільки збирали, а вони вже требують... «Давай вже...» Нам мали бути поощрєнія, ми мали мати права на все, нас не повинні були таке заставляти, а вони забирали все підряд. В 1947 році ми вже і сіяли. Вони требували: і зерно давай, і молоко, і яйця здавай. Молока мало було. Забрали зерноочисну машинку. Корови були в основному робочі, запрягали їх. Але мусили все здавати.

У нас по сусідству жили Чапістраки, там було два брати. Жінки старшого з братів якраз не було вдома. Вони вчепилися до нього: «Здавай зерно вже і вже». Він каже, що ще не змолотив. А вони все чіпляються...Тут я бачу, як мій брат Михайло сильно біжить. А виявляється, що той старший брат не витримав, нерви здали, взяв шнурка і йде вішатись. А молодший брат став кричати, наш Міша почув і дуже скоро побіг. А Міша був спортсмен, чемпіоном колись був. То Міша зловив старшого Чапістрака, почав стримувати його, забрали того шнурка. Жінка як потім прийшла і те почула, то так сильно кричала... 
Міша потім був чемпіоном України по пожежно-прикладному спорту, багато нагород мав. Їх тут у Луцьку двоє таких було: ще Денисюк такий був...

Міша одружився на Черняковій Маргариті з Боратина, словачці. Словаки спочатку сильно трималися своїх, старалися одружуватися зі словаками, все думали, що пустять і вони поїдуть назад....

... Коня в нас забрали, розібрали клуню. Зробили в селі конюшню, там було зо 60 коней. То тато до самої пенсії пропрацював конюхом. Їх там троє було. Там коні були такі доглянуті, я пам’ятаю, ми не раз їсти носили татові, вони, бідолахи, навіть не мали, коли прийти поїсти. То вони пасли ті коні в Новоставі, чергували по сутках, то кожен день чистили все. А трудодні заробляв на місяць. Потім і я попала на роботу, то заробляли: він - 60 трудоднів, і я - 60 трудоднів. Пройде рік - і ти не знаєш, скільки ти тих копійок заробиш. Давали раз на півроку, і то не всім вистачало. Як вже мали платити, то біля тої каси купа людей збиралась, такий гвалт стояв. Грошей дуже не хватало. Як мали яке телятко, то шо могли з'їсти, то тато завжди продавав, бо ж треба гроші...

В 1960 р. тато перший раз поїхав у Словаччину в отпуск.

Трьом сестрам вдалося виїхати назад. Одна сестра, Тереза, 1942 р. н., поїхала в 1969 р.. Вона була неодружена і поїхала в Словаччину. Жила вона там у маминої сестри в Лютині. Там вийшла заміж за словака і залишилась.

Усі словаки хотіли додому, бо то батьківщина...

Потім друга сестра, Гелена, 1937 р. н., тяжка робота в неї була, грузчиком працювала, то взяла довідку, що неодружена, поїхала і теж вийшла заміж за словака.

Третя сестра Іра виїхала у 1993 р. як чорнобилець.

Я закінчила школу. Рік вчилась у Володимирі в школі з підготовки бухгалтерів і архівників колгоспів, із листопада починаючи. Я теж дуже хотіла їхати. Але чоловік був геть проти. І ми залишились. Разом зі мною залишилися Михайло, Марія, Ольга, і Андрій» [3].

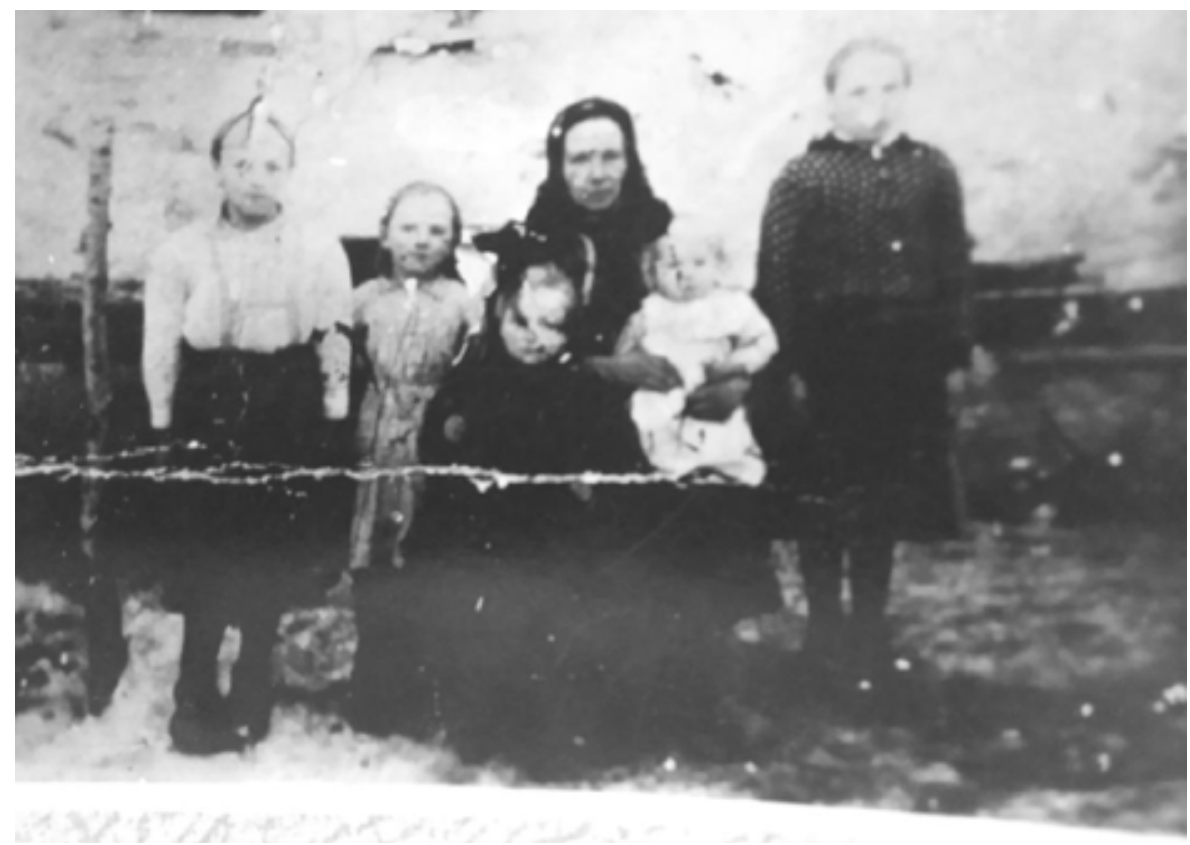

Рис. 1. На фото - Анна Андріївна Залета з доньками. Друга зліва - Ганна Матвіївна Залета. Село Лютина, Словаччина, осінь 1947 року. Фото з домашнього архіву Ганни Матвіївни Зай (дівоче прізвище - Залета)

На сайті Волинської обласної організації Фізкультурно-спортивного товариства «Динамо» України в розділі «Історія» є інформація про спортивні досягнення Михайла Матвійовича Залети, зокрема зазначено:

«Значну увагу обласна рада «Динамо» приділяє роботі секції з пожежно-прикладного спорту, яку очолював видний спеціаліст, громадський тренер Бродський Георгій Леонтійович, а естафету від нього прийняли ЗТУ Сацик С.І., МС Бахтай С.П., МСМК Немченко Я.О., ЗМСУ Сафатюк Ю.П. Під їх керівництвом протягом 42 років славні спортсмени-пожежники - П. Денисюк, М. Залета, А. Зудихін, Б. Мельник, А. Касич, М. Марицький, Я. Немченко та багато інших - виходили переможцями і призерами всеукраїнських і міжнародних змагань із цього красивого і мужнього виду спорту» [4]. 
Таким чином, можна сказати, що оптація населення зі Східної Словаччини у 1947 р. є суперечливою за наслідками, залишивши в спадок сучасності багато проблем.

Оптанти, прибувши на територію Радянського Союзу, змушені були докладати значних зусиль до облаштування житла i налагодження побуту, встановлення земельних ділянок та їхніх меж, влаштування дітей. Адаптація оптантів проходила складно через незнання ситуації в повоєнній Волині. До того ж не знали ні мови, ні історії, ні культури, ні звичаїв, була інша ментальність. Проте найбільшою загрозою для переселенців стала колективізація, оскільки вони були впевнені, що матимуть пільги. До цього додавалося протистояння в житловому питанні між переселенцями з Польщі і переселенцями з Чехословаччини: коли стало відомо про виїзд волинських чехів, переселенці 3 Польщі часто самовільно почали вселятись в їхні будинки.

Мешканців Східної Словаччини агітатори зацікавлювали економічними факторами переселення, натомість національний фактор відігравав другорядну роль. Якщо в Чехословаччині рееміграція мала організований характер і проблеми, що виникали, влада вирішувала, то на Волині робота державних органів полягала в контролі і була спрямована переважно на ретельний облік і подальше використання в інтересах держави усіх матеріальних ресурсів. Більшість волинських оптантів із Пряшівщини перетворилися на словацьких реоптантів другої половини 1990-х років.

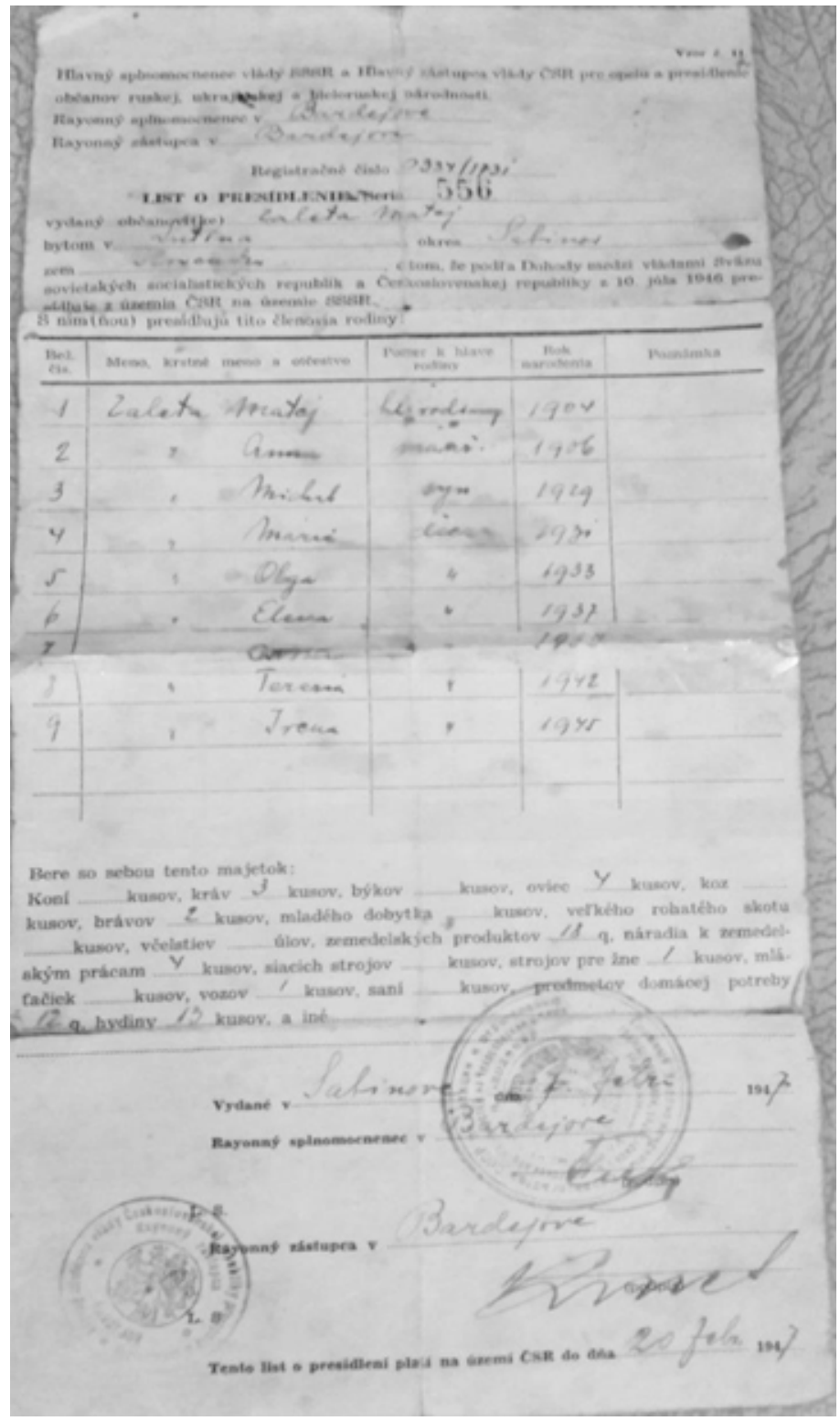

Рис. 2. Переселенський лист, виписаний в 1947 році на ім'я Матвія Залети. Фото зроблене з оригіналу з домашнього архіву Ганни Матвіївни Зай (дівоче прізвище - Залета)

\section{Література:}

1. Вовканич Іван, Сюсько Іван. Оптація між ЧСР і СРСР в 1945-1947 pp. та проблеми мови і освіти. URL: http://www.clovekaspolocnost.sk/jquery/pdf.php?gui=A68S4RSPQRMQE8E42GGZBI5

2. У межиріччі Чорногузки та Стиру. Сторінки історії сіл Боратин, Голишів, Новостав та Рованці Луцького району / Упоряд. В. Гнатюк. Кн. І. Луцьк : Волинська обласна друкарня, 2006. 91с.

3. Записано зі слів Зай Ганни Матвіївни (дівоче прізвище - Залета). Запис зроблено 16 грудня 2020 року.

4. Історія. URL: http://dynamo.lutsk.ua/istoriia/. 